\title{
Sinalbin degradation products in mild yellow mustard paste
}

\author{
Dragana Paunović ${ }^{1}$, Tatjana Šolević Knudsen ${ }^{2}$, Mirjana Krivokapić ${ }^{1}$, Branislav Zlatković $^{1}$, Mališa Antić ${ }^{1,2}$ \\ ${ }^{1}$ University of Belgrade, Faculty of Agriculture, Belgrade, Serbia \\ ${ }^{2}$ University of Belgrade, Institute of Chemistry, Technology and Metallurgy, Department of Chemistry, Belgrade, Serbia
}

\begin{abstract}
Sinalbin degradation products in mild yellow mustard paste were investigated. The analyzed material consisted of a mild yellow mustard paste condiment and ground white mustard seeds which were originally used in the mustard paste production process. The samples were extracted in a Soxhlet extraction system and analyzed by gas chromatography-mass spectrometry (GC-MS) technique. The only sinalbin degradation product in ground mustard seeds was 2-(4-hydroxyphenyl)acetonitrile. The most abundant sinalbin degradation product in yellow mustard paste was 4-(hydroxymethyl)phenol. Other compounds identified in this sample were: 4-methyl phenol, 4-ethyl phenol, 4-(2-hydroxyethyl)phenol and 2-(4-hydroxyphenyl) ethanoic acid.
\end{abstract}

Keywords: mild mustard paste; sinalbin degradation products; extraction; GC-MS.
PROFESSIONAL PAPER

UDC 664.53:543.544.3.547.918

Hem. Ind. 66 (1) 29-32 (2012)

doi: 10.2298/HEMIND110627055P

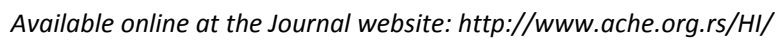

Mustard is a condiment made from whole, powdered or crushed dried seeds of mustard plants: Brassica nigra (black mustard), Brassica juncea (brown mustard) or Sinapis alba (white mustard). The seeds are usually mixed with wine, vinegar, water and various spices to create a paste ranging in color from bright yellow to dark brown.

Mustard plants keep attracting a lot of attention since they have been recognized as a functional food for health maintenance and disease prevention $[1,2]$. Chemical composition of aroma and flavor compounds in mustard seeds has been investigated in details [3-5], as well as composition of dominant fatty acids present in these oilseeds [6].

The pungent aroma and flavor of mustard seeds is derived from glucosinolates, which are hydrolyzed by the enzyme commonly known as myrosinase, in the presence of water, to flavor-active isothiocyanates. Glucosinolate sinigrin (associated with black and brown mustard seeds) yields the volatile 3-isothiocyanato-1-propene, a compound responsible for the pungent burning odor and taste. Glucosinolate sinalbin (characteristic of white mustard seeds) primarily yields the 4-(isothiocyanatomethyl)phenol, a compound which is only slightly volatile and contributes significantly to the sharp pungent taste of mustard [7]. 4-(Isothiocyanatomethyl)phenol is unstable and can be further decomposed to a variety of compounds, the composition of which depends on $\mathrm{pH}$, metal ions and proteins [8].

Correspondence: T. Šolević Knudsen, Department of Chemistry, Institute of Chemistry, Technology and Metallurgy, University of Belgrade, Njegoševa 12, P.O.Box 473, 11001 Belgrade, Serbia.

E-mail: tsolevic@chem.bg.ac.rs

Paper received: 27 June, 2011

Paper accepted: 2 August, 2011
Although the chemical composition of mustard seeds, as well as degradation pathways of related glucosinolates, have been investigated in detail, only a few papers on the chemical composition of mustard paste created from brown and black mustard have been published so far $[9,10]$, and to the best of our knowledge, there has been no detailed investigation of a chemical composition of a mild mustard paste.

Here we report the results of our investigation of sinalbin degradation products in mild yellow mustard paste using solvent extraction and GC-MS analysis.

\section{MATERIAL AND METHODS}

The investigated material consisted of two samples: a mild yellow mustard paste condiment and ground white mustard seeds which were originally used in the mustard paste production process. Both samples were obtained from a local producer.

The mustard paste condiment was made from the ground white mustard seeds, water, vinegar, oil, sugar, salt, spices and yellow pigment. The $\mathrm{pH}$ of the final product was in the 3.4-4.2 range. The maximum temperature during the production process was $75^{\circ} \mathrm{C}$.

During the mustard paste production process, ground yellow mustard seeds were pretreated according to the original manufacturer's procedure. Industrially processed mustard seeds were analyzed in the same way as the mustard paste. The aim of this analysis was to check for any similarities or differences between the chemical composition of the original mustard seeds and final mustard paste product, as well as to check the reliability of the analytical method employed.

Before the analysis the samples were kept in a dark and cold storage.

The samples were extracted in a Soxhlet extraction system over $10 \mathrm{~h}$ using methylene-chloride (b.p. $38^{\circ} \mathrm{C}$ ) 
as a solvent. All analyzes were done in triplicates. With each set of samples a solvent blank was passed through the extraction and GC-MS analytical procedure.

The extracts were analyzed by gas chromatography -mass spectrometry (GC-MS) techniques. An Agilent $7890 \mathrm{~N}$ gas chromatograph fitted with a HP5-MS capillary column (temperature range: $40{ }^{\circ} \mathrm{C}$ for $9 \mathrm{~min}$, then $4{ }^{\circ} \mathrm{C} / \mathrm{min}$ to $65{ }^{\circ} \mathrm{C}$ for $0 \mathrm{~min}$, then $9{ }^{\circ} \mathrm{C} / \mathrm{min}$ to $285^{\circ} \mathrm{C}$ for $3 \mathrm{~min}$ ) with helium as the carrier gas (flow rate 1.5 $\mathrm{cm}^{3} / \mathrm{min}$ ) was used. The extracts were injected manually ( $1 \mu$ l of the sample) and analyzed in the splitless mode. The injector temperature was $250{ }^{\circ} \mathrm{C}$. The GC was coupled to a Hewlett-Packard 5972 MSD operated at $70 \mathrm{eV}$ in the $45-550$ scan range. The source temperature was $230{ }^{\circ} \mathrm{C}$, and the quadrupole temperature was $150{ }^{\circ} \mathrm{C}$. The solvent delay was $10 \mathrm{~min}$. All analyzes of the investigated samples were conducted in a full scan mode. The most relevant peaks were identified by comparison of their retention indices with literature data and on the basis of their total mass spectra, by comparison with mass spectra databases (NIST/EPA/ /NIH mass spectral library NIST2000, Wiley/NBS Registry of Mass spectral Data $7^{\text {th }}$ ed., electronic versions). Retention indices were calculated relative to $C_{7}-C_{29}$ alkanes on the HP-5MS column, according to the Kovats Equation [11].

\section{RESULTS AND DISCUSSION}

The results of GC-MS analyzes of the white mustard seeds are shown in Figure 1.

The GC-MS analysis of the extract from the white mustard seeds confirmed previous results [5]. As expected, the dominant compounds in the extract of this sample were numerous saturated and mono-, di- and tri-unsaturated fatty acids having 16-24 carbon atoms. Unfortunately, the chromatogram was dominated by a broad and prominent "hump" of an unresolved complex mixture (UCM) of fatty acids, indicating poor resolution of these compounds under experimental conditions used. As a consequence, precise identification and quantification of all fatty acids in the sample investigated, using these results, were not possible. However, the most abundant fatty acids in this sample were identified as: oleic, linoleic, linolenic, eicosenoic and erucic, confirming previous results [6].

In the range of lower retention times, the most abundant compound was 2-(4-hydroxyphenyl)acetonitrile (characteristic fragmentation ions in mass spectrum $(\mathrm{m} / \mathrm{z}): 78,106$ and 133). This compound is one of the main degradation products of glucosinolate sinalbin, catalyzed by the enzyme myrosinase $[8,12,13]$. 4-(Isothiocyanatomethyl)phenol, the pungent degradation product of sinalbin, has not been detected in this sample. These results confirmed that 4-(isothiocyanatomethyl)phenol is an unstable sinalbin's degradation intermediate during industrial pretreatment process used for preparation of the Sinapis alba seeds.

No other compounds which can be related to sinalbin or its degradation products were identified in these ground mustard seeds.

The results of GC-MS analysis of the mustard paste condiment are shown in Figure 2.

Similarly to the extract from the white mustard seeds, this chromatogram was also dominated by a UCM of fatty acids. Again, due to their poor resolution under experimental conditions employed, only the identification of the most abundant fatty acids in this sample was possible. Namely, they are: oleic, linoleic, linolenic, eicosenoic and erucic.

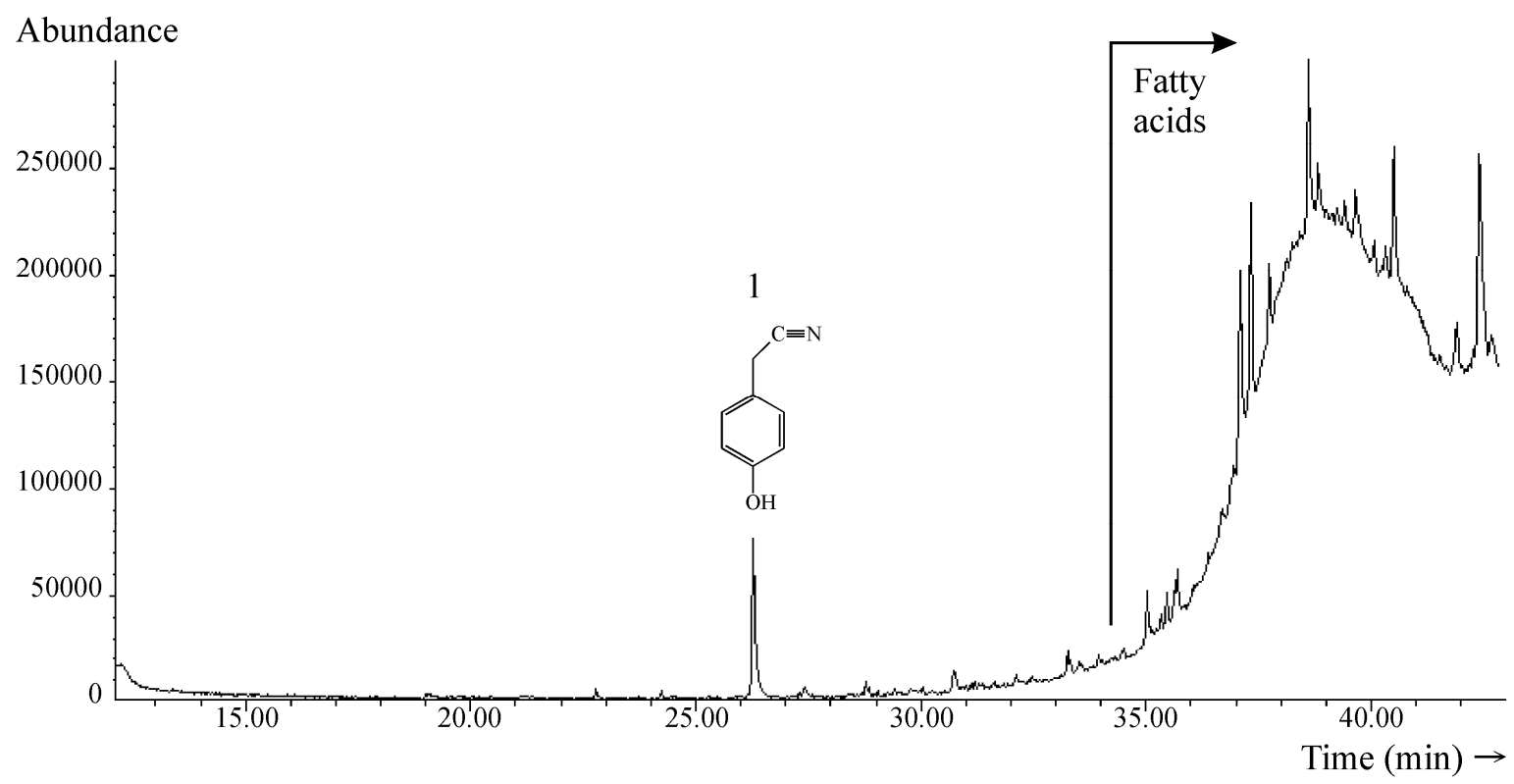

Figure 1. Total ion chromatogram (TIC) of the extract from the analyzed white mustard seeds (1: 2-(4-hydroxyphenyl)acetonitrile). 


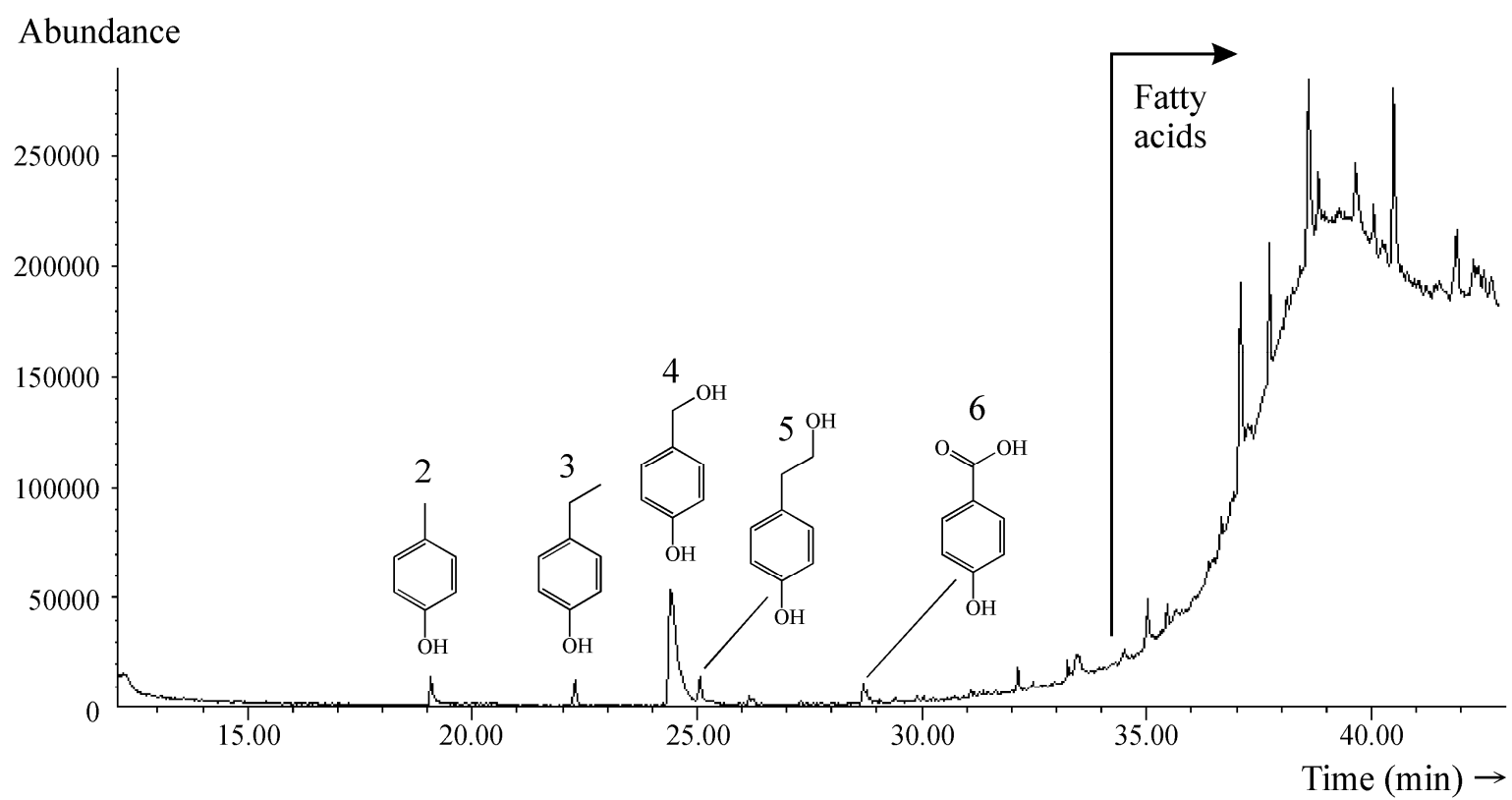

Figure 2. Total ion chromatogram (TIC) of the extract from the analyzed mild yellow mustard paste condiment (2: 4-methyl phenol; 3: 4-ethyl phenol; 4: 4-(hydroxymethyl)phenol; 5: 4-(2-hydroxyethyl)phenol; 6: 2-(4-hydroxyphenyl)ethanoic acid).

These results indicate that the dominant fatty acids, originally present in the white mustard seeds, are also present in the mustard paste condiment made from this plant.

In the range of lower retention times, the most abundant compound was 4-(hydroxymethyl)phenol ( $\mathrm{Fi}$ gure 2; characteristic fragmentation ions in mass spectrum $(\mathrm{m} / \mathrm{z}): 77,95,107$ and 124). Considering the fact that glucosinolate sinalbin on hydrolysis by myrosinase gives an unstable isothiocyanate which decomposes, directly or via 2-(4-hydroxyphenyl)acetonitrile, to 4-(hydroxymethyl)phenol, these results can be characterized as expected $[8,12,13]$.

Other compounds identified in the range of lower retention times were: 4-methyl phenol (characteristic fragmentation ions in mass spectrum $(\mathrm{m} / \mathrm{z}): 77,79,107$ and 108), 4-ethyl phenol (characteristic fragmentation ions in mass spectrum $(\mathrm{m} / \mathrm{z}): 77,107$ and 122), 4-(2-hydroxyethyl)phenol (characteristic fragmentation ions in mass spectrum $(\mathrm{m} / \mathrm{z}):$ 77, 107 and 138$)$ and 2-(4-hydroxyphenyl)ethanoic acid (characteristic fragmentation ion in mass spectrum $(\mathrm{m} / \mathrm{z})$ : 107). These compounds were present in the mustard sample in a much lower amount then 4-(hydroxymethyl)phenol (Figure 2). Although some of them can be structurally related to the glucosinolate sinalbin $[8,13]$, this connection has yet to be proven.

2-(4-Hydroxyphenyl)acetonitrile, one of the main degradation products of glucosinolate sinalbin [12], and one of the main precursors of 4-(2-hydroxyethyl)phenol during sinalbin degradation reaction [8], has not been detected in this sample. These results confirmed that 2 - -(4-hydroxyphenyl)acetonitrile is unstable under conditions used for industrial production of this mustard paste condiment.

4-(Isothiocyanatomethyl)phenol, the pungent degradation product of sinalbin, has not been detected in this sample, indicating that this compound is not responsible for the pungent taste of the investigated mustard condiment.

\section{CONCLUSIONS}

In this study, experiments were conducted with the aim of investigating sinalbin degradation products in the mild yellow mustard paste condiment. The results were compared with the analysis of the ground white mustard seeds which were originally used in the mustard paste production process.

These results indicate that the dominant fatty acids, originally present in the white mustard seeds, are also present in the mustard paste condiment made from this plant.

The most abundant sinalbin degradation product in the mustard paste was 4-(hydroxymethyl)phenol. Other compounds identified in this condiment were: 4-methylphenol, 4-ethylphenol, 4-(2-hydroxyethyl)phenol and 2-(4-hydroxyphenyl)ethanoic acid. Although some of them can be structurally related to the glucosinolate sinalbin, this connection has yet to be proven.

2-(4-Hydroxyphenyl)acetonitrile, one of the main degradation products of glucosinolate sinalbin, and one of the main precursors of 4-(2-hydroxyethyl)phenol during sinalbin degradation reaction, has not been de- 
tected in this sample, indicating that this compound is unstable under conditions used for industrial production of this mustard paste condiment.

4-(Isothiocyanatomethyl)phenol, the pungent degradation product of sinalbin, has not been detected in the mustard sample, indicating that this compound is not responsible for the pungent taste of the investigated mustard condiment.

\section{Acknowledgments}

This work was supported by the Ministry of Education and Scienceof the Republic of Serbia (Project No. 46009).

\section{REFERENCES}

[1] G. van Poppel, D.T. Verhoeven, H. Verhagen, R.A. Goldbohm, Brassica vegetables and cancer prevention. Epidemiology and mechanisms, Adv. Exp. Med. Biol. 472 (1999) 159-168.

[2] H.Y. Kim, T. Yokozawa, E.J. Cho, H.S. Cheigh, J.S. Choi, H.Y. Chun, In Vitro and in vivo antioxidant effects of mustard leaf (Brassica juncea), Phytother. Res. 17 (2003) 465-471.

[3] N. Frank, M. Dubois, T. Goldmann, A. Tarres, E. Schuster, F. Robert, Semiquantitative analysis of 3-butenyl isothiocyanate to monitor an off-flavor in mustard seeds and glycosinolates screening for origin identification, J. Agric. Food. Chem. 58 (2010) 3700-3707.

[4] U.P. Singh, D.P. Singh, S. Maurya, R. Maheshwari, M. Singh, R.S. Dubey, R.B. Singh, Investigation on the phe- nolics of some spices having pharmacotherapeuthic properties, J. Herb. Pharmacother. 4 (2004) 27-42.

[5] M. Miyazawa, K. Jyunichi, Identification of the main aroma compounds in dried seeds of Brassica hirta, J. Nat. Med. 60 (2006) 89-92.

[6] S. Samman, J.W.Y. Chow, M.J. Foster, Z.I. Ahmad, J.L. Phuyal, P.Petocz, Fatty acid composition of edible oils derived from certified organic and conventional agricultural methods, Food Chem. 109 (2008) 670-674.

[7] H.D. Belitz, W. Grosch, P. Schieberle, Food Chemistry, $4^{\text {th }}$ ed., Springer, 2009.

[8] A.M. Bones, J.T. Rossiter, The enzymic and chemically induced decomposition of glucosinolates, Phytochem. 67 (2006) 1053-1067.

[9] K. Cejpek, J. Urban, J. Velísek, H. Hrabcová, Effect of sulphite treatment on allyl isothiocyanate in mustard paste, Food Chem. 62 (1998) 53-57.

[10] J. Cai, B. Liu, Q. Su, Comparison of simultaneous distillation extraction and solid-phase microextraction for the determination of volatile flavor components, J. Chromatogr., A 930 (2001) 1-7.

[11] E. Kováts, Gas-chromatographische Charakterisierung organischer Verbindungen. Teil 1: Retentionsindices aliphatischer Halogenide, Alkohole, Aldehyde und Ketone, Helv. Chim. Acta 41 (1958) 1915-1932.

[12] S. Buskov, J. Hasselstrøm, C.E. Olsen, H. Sørensen, J.C. Sørensen, S. Sørensen, Supercritical fluid chromategraphy as a method of analysis for the determination of 4-hydroxybenzylglucosinolate degradation products, J. Biochem. Biophys. Methods 43 (2000) 157-174.

[13] R.F. Mithen, Glucosinolates and their degradation products, Adv. Botan. Res. 35 (2001) 213-232.

\section{IZVOD}

\section{DEGRADACIONI PROIZVODI SINALBINA U BLAGOM SENFU}

Dragana Paunović ${ }^{1}$, Tatjana Šolević Knudsen ${ }^{2}$, Mirjana Krivokapić ${ }^{1}$, Branislav Zlatković ${ }^{1}$, Mališa Antić ${ }^{1,2}$

${ }^{1}$ Univerzitet u Beogradu, Poljoprivredni fakultet, Beograd, Srbija

${ }^{2}$ Univerzitet u Beogradu, Institut za hemiju, tehnologiju i metalurgiju, Centar za hemiju, Beograd, Srbija

\section{(Stručni rad)}

Ispitivani su degradacioni proizvodi sinalbina u blagom senfu. Ispitivani materijal se sastojao od blagog senfa i od mlevenog semena bele slačice koja je korišćena u procesu proizvodnje senfa. Uzorci su ekstrahovani u Soxhlet-ovom ekstraktoru i analizirani gasno hromatografsko-masenospektrometrijskom (GC-MS) tehnikom. Jedini degradacioni proizvod sinalbina identifikovan u mlevenom semenu slačice je 2-(4-hidroksifenil)acetonitril. Najobilniji degradacioni proizvod sinalbina u blagom senfu je 4-(hidroksimetil)fenol. Druga jedinjenja identifikovana u ovom uzorku su: 4-metilfenol, 4-etilfenol, 4-(2-hidroksietil)fenol i 2-(4-hidroksifenil) etanska kiselina. Ova jedinjenja bila su prisutna u uzorku senfa u znatno manjoj količini nego 4-(hidroksimetil)fenol. lako se za neka od njih može reći da su strukturno srodna sa glukozinolatom sinalbinom, ovaj odnos tek treba dokazati. 4-(Izotiocianatometil)fenol, ljuti degradacioni proizvod sinalbina, nije identifikovan u ispitivanom mlevenom semenu slačice niti u ispitivanom uzorku senfa. Ovi rezultati su pokazali da je 4-(izotiocianatometil)fenol nestabilan intermedijer degradacije sinalbina pod uslovima industrijskog procesa pripreme semena bele slačice i dodatno, da ovo jedinjenje ne doprinosi ljutom ukusu ispitivanog senfa.
Ključne reči: Blagi senf • Degradacioni proizvodi sinalbina $\bullet$ Ekstrakcija $\bullet$ GC-MS 